\title{
First records of the flat-headed cat Prionailurus planiceps on the Kampar Peninsula, Sumatra, Indonesia
}

\author{
Chela Powell and Muhammad IQbal
}

\begin{abstract}
The flat-headed cat Prionailurus planiceps is one of the rarest small felids, with little known about its distribution, population status or habitat requirements, largely because of the few records of the species. We report here 11 detections of this Endangered species, recorded during 4 years of camera-trap surveys in a peat-swamp forest on the Kampar Peninsula, Riau province, Sumatra. These are the first records of this species on the Kampar Peninsula, in an area of c. $1,300 \mathrm{~km}^{2}$ of peat-swamp forest comprising four adjacent Ecosystem Restoration Concession licences. All records were near water bodies (mean distance $351 \mathrm{~m}$ ) in lowland peat-swamp forest. These findings add to the existing knowledge of the species' distribution in Sumatra and confirm its presence in these peat-swamp forests. To inform species conservation management planning for the Kampar Peninsula, further research on this species is required.
\end{abstract}

Keywords Flat-headed cat, Indonesia, Kampar Peninsula, peat-swamp forest, Prionailurus planiceps, Restorasi Ekosistem Riau, small felid, Sumatra

$\mathrm{O}$ the small felids, the flat-headed cat Prionailurus planiceps, which occurs only in Borneo, Kalimantan, Sumatra and Peninsular Malaysia, is one of the rarest. Little is known about its ecology and behaviour (Wilting et al., 2010, 2015; Wadey et al., 2016), apart from it having a strong link to semi-aquatic environments such as peat-swamp forests (Cheyne \& Macdonald, 2011). Modelling the predicted distribution of the flat-headed cat has shown that most detections were at $<200 \mathrm{~m}$ altitude and within $5 \mathrm{~km}$ of large rivers and lakes (Wilting et al., 2010). This close association with water is reflected in unique anatomical adaptations such as a slight webbing between toes, a flattened skull, small ears and, for its size, large canine teeth, presumably to assist in the capture of aquatic prey such as fish and amphibians (Muul \& Lim, 1970). The flat-headed cat is categorized as Endangered on the IUCN Red List (Wilting et al., 2015) because of habitat

Chela Powell (Corresponding author, (D) orcid.org/0000-0003-0968-8537) Riau Ekosistem Restorasi, PT RAPP Town site 1, Rukon Akasia, Blok III, No. 1 Pangkalan Kerinci, Riau 28300, Indonesia. E-mail cjrpowell@gmail.com

Muhammad Iqbal Riau Ecosystem Restoration, Pangkalan Kerinci, Indonesia

Received 16 June 2020. Revision requested 24 September 2020.

Accepted 22 January 2021. First published online 15 September 2021. loss and fragmentation through degradation and land conversion, contamination of prey through water pollution, and overfishing. An additional threat is the drainage of peatswamp forests by man-made canals, resulting in the loss of permanent water and increased hydraulic instability (Jeffers et al., 2019).

Despite the proliferation of camera-trap surveys across South-east Asia, there is a paucity of records of the flatheaded cat, particularly in Sumatra, with records more common in Borneo (Wilting et al., 2016). The lack of information on the flat-headed cat may be a result of its rareness, the lack of species-specific studies, and/or the fact that lowland flood plains are under-represented in camera-trap studies (Wadey et al., 2016; Jeffers et al., 2019). Wadey et al. (2016) commented on the importance of making any records of the flat-headed cat publicly available, and Zanin et al. (2014) noted the species requires urgent research attention because of the risk of extinction.

Lying between the Malacca Straights to the north and the Kampar River to the south, the $7,200 \mathrm{~km}^{2}$ Kampar Peninsula is a coastal plain in Riau Province on the east coast of Sumatra, located within the larger Central Sumatran basin and part of the Sundaic region of South-east Asia. The Peninsula is dominated by peat-swamp forest thought to have formed within the past 8,00o years (Dommain et al., 2011). The central core of this landscape comprises $3,445 \mathrm{~km}^{2}$ of dense natural forest, with two peat domes, the western being larger than the eastern. Peat depth varies from none at the coastline to $\mathrm{c} .15 \mathrm{~m}$ in the interior peat domes, which are the highest points in the study area.

The Kampar Peninsula comprises various land uses, including commercial fibre production (c. $2,260 \mathrm{~km}^{2}$ ) and oil palm plantations (c. $304 \mathrm{~km}^{2}$ ), located on the peripheral edges of the Peninsula. In the centre of the Peninsula natural forest areas comprise c. $409 \mathrm{~km}^{2}$ of protected forest and c. $1,301 \mathrm{~km}^{2}$ of Ecosystem Restoration Concessions, covering the peat domes, under the Restorasi Ekosistem Riau programme (Fig. 1). These Concessions are provided by the Indonesian government and designed specifically to restore the productivity of degraded forest, protect biodiversity and achieve ecosystem balance (Decree 159/Menhut-II/ 2004; Government Regulation (GR) No. 6/2007). This regulation provides an alternative to the conversion of forests to either timber or oil palm plantations, providing the opportunity for companies to acquire a licence to manage degraded production forest land for protection, restoration 


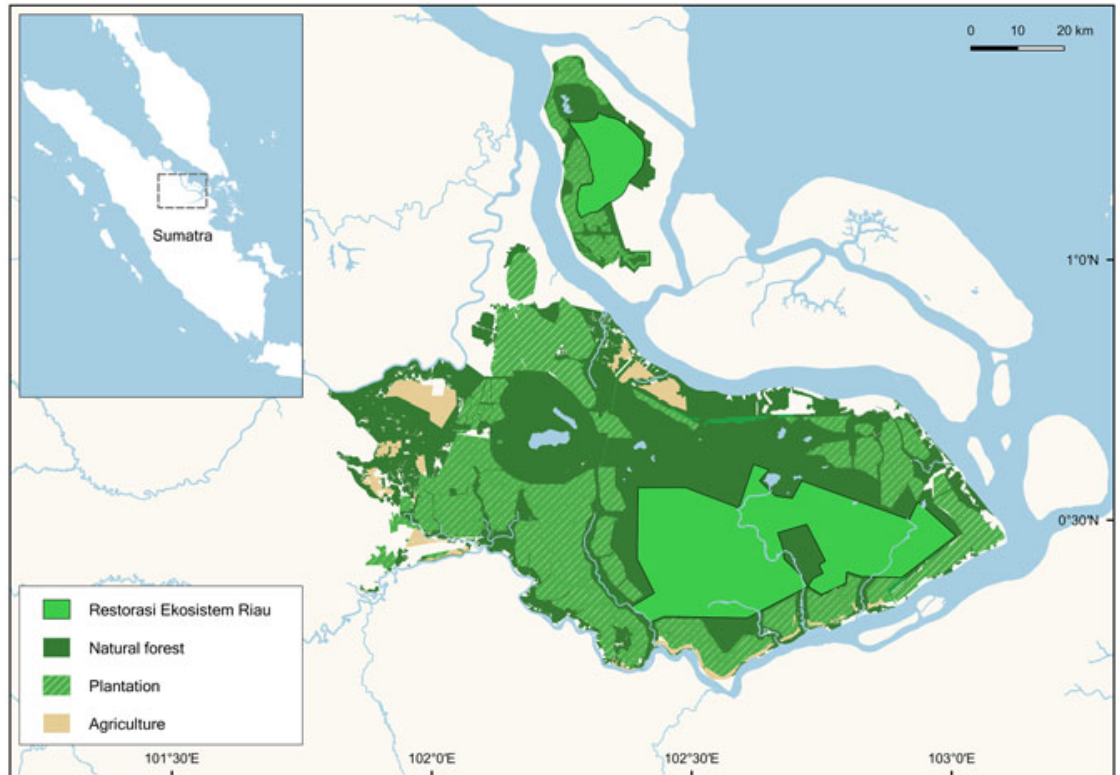

Fig. 1 The Kampar Peninsula, Sumatra, Indonesia, indicating the Restorasi Ekosistem Riau area where camera traps were deployed to detect the flat-headed cat Prionailurus planiceps. and conservation, instead of being required to harvest timber. The Restorasi Ekosistem Riau area comprises four adjacent Concessions on the Kampar Peninsula and one of c. $200 \mathrm{~km}^{2}$ on Padang Island, to the north. These Concessions are held and funded by the pulp and paper company Asia Pacific Resource International Holdings for 60 years. The Restorasi Ekosistem Riau area is delineated into three management zones (Table 1). Since 2015, surveys of fish, amphibians, reptiles, birds, mammals, plants and specific groups of invertebrates have been undertaken across the area, using a variety of methods, including camera trapping, to provide a baseline inventory of species. Here, we report the detections of the flat-headed cat.

A total of 350 camera traps were established across c. 925 $\mathrm{km}^{2}$ of three of the four Concessions of the Restorasi Ekosistem Riau area in 2015. Camera traps were positioned singly and paired, alternately, across $2202 \times 2 \mathrm{~km}$ grid cells, in locations selected based on the occurrence of scent marks, scats and wildlife trails. Cameras were mounted on trees, $40-50 \mathrm{~cm}$ above the ground. Single camera stations were set to capture video, with a duration of $10 \mathrm{~s}$, and paired camera stations to take still photographs with a 10-s time interval. All cameras were Trophy Cam type HD (Bushnell, Overland Park, USA). In 2018 we adjusted the survey design to cover a larger area: using only single cameras, we surveyed c. $984 \mathrm{~km}^{2}$ using the same protocols as for 2015-2017, with the addition of Hyperfire $\mathrm{HF}_{2} \mathrm{X}$ and $\mathrm{HC}_{5} \mathrm{Oo}$ cameras (Reconyx, Holmen, USA). Camera-trap effort across the sampling period 2015-2019 is summarized in Table 2.

During 2015-2019 the camera traps detected five of the six felid species known from Sumatra: the leopard cat Prionailurus bengalensis, marbled cat Pardofelis marmorata and flat-headed cat, Sunda clouded leopard Neofelis diardi, and Sumatran tiger Panthera tigris sondaica. The flatheaded cat was recorded five times in 2015 , once each in 2017 and 2018, and four times in 2019; the latter records were $4.5-23.8 \mathrm{~km}$ apart. Given that these 11 records span 5 years and an area of c. $768 \mathrm{~km}^{2}$, they are likely to represent multiple individuals. The mean distance to a water source, such as a river or old drainage canal (the latter constructed for extraction of timber) was $351 \mathrm{~m}$, with the farthest being $1.2 \mathrm{~km}$, and the closest being on a river bank. The 11 records were at a mean altitude of $4 \mathrm{~m}$ (range $1-7 \mathrm{~m}$ ). Forest type was relatively uniform across sites where the flat-headed cat was detected, comprising riparian and mixed peat-swamp forest, which was partly degraded where past selective logging has removed large diameter trees. Consistent with most previous reports, 10 of the records were during 18.30-6.00, with most during 22.00-01.00, emphasizing that the species is largely crepuscular-nocturnal (Nowell \& Jackson, 1996; Bezuijen, 2000; Meijaard et al., 2005). Diurnal activity is rare (e.g. in Central Kalimantan; Jeffers et al., 2019) and only one of our records was during the day, at 16.21 (Plate 1).

The flat-headed cat has been detected only rarely by camera traps (Wadey et al., 2016; Hearn et al., 2018; Jeffers et al., 2019), and thus these records are of particular importance, especially in Sumatra where there have been few previous published accounts of the species (Wilting et al., 2010). The 11 records indicate the importance of the Restorasi Ekosistem Riau area for this species. A species distribution model for the flat-headed cat predicted that Riau Province is the largest remaining forest suitable for the species in Sumatra (Wilting et al., 2010). This model was built with both recent (post 1984) and historical (pre 1984) records of the species, with a total of 107 records across the species' range, 19 of which were from Sumatra but none from the Kampar 
TABle 1 Management zones in the Restorasi Ekosistem Riau of the Kampar Peninsula, Sumatra, Indonesia (Fig. 1).

\begin{tabular}{ll}
\hline Management zone & Description \& objectives \\
\hline $\begin{array}{l}\text { Conservation } \\
\text { Zone }\end{array}$ & $\begin{array}{l}\text { Includes all areas of deep peat }(>3 \mathrm{~m}) \& \text { the full range of forest cover types. The primary purpose is } \\
\text { long-term storage of carbon, restoration of degraded areas \& conservation of the fauna \& flora unique to } \\
\text { this wetland biome. }\end{array}$ \\
$\begin{array}{l}\text { Production } \\
\text { Zone }\end{array}$ & $\begin{array}{l}\text { Can only legally occur on peat areas }<3 \mathrm{~m} \text { deep. In these areas past harvesting \&/or intensive community } \\
\text { use (e.g. sagu or rubber plantations) predate the ecosystem restoration licenses, \& occur only on Padang }\end{array}$ \\
& $\begin{array}{l}\text { Island. No native timber harvesting will be proposed or implemented during the current or future license } \\
\text { periods, \& only agroforestry community use of these areas is permitted. }\end{array}$ \\
$\begin{array}{l}\text { Non-production } \\
\text { Zone }\end{array}$ & \begin{tabular}{l} 
management \& access. \\
\hline
\end{tabular}
\end{tabular}

TABLE 2 Camera-trapping effort for the flat-headed cat Prionailurus planiceps during 2015-2019 in the Restorasi Ekosistem Riau area of the Kampar Peninsula, Sumatra, Indonesia.

\begin{tabular}{llcc}
\hline Year & Period & $\begin{array}{l}\text { Number of } \\
\text { cameras }\end{array}$ & $\begin{array}{l}\text { Camera-trap } \\
\text { nights }\end{array}$ \\
\hline 2015 March-November (9 months) & 350 & 11,385 \\
2017 March-October (8 months) & 69 & 6,843 \\
2018 January-May (5 months) & 57 & 2,648 \\
2019 April-December (9 months) & 62 & 5,774 \\
Total & & 26,650 \\
\hline
\end{tabular}

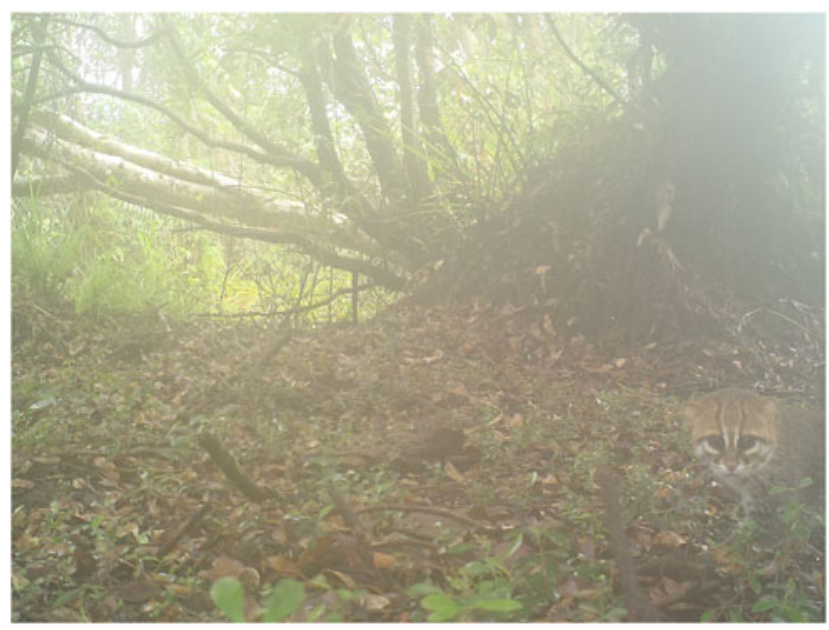

Plate 1 A flat-headed cat Prionailurus planiceps, detected in lowland peat-swamp forest on the Kampar Peninsula, Sumatra, Indonesia (Fig. 1) at 16.21 on 4 October 2019. This was our only diurnal record of the species.

Peninsula. This model was used to provide the distribution of the flat-headed cat for the IUCN Red List (Wilting et al., 2015). Our findings provide the first published evidence of the species presence on the Kampar Peninsula, and suggest the area is an important refuge for this Endangered felid.

Although the Kampar Peninsula has experienced forest conversion, peat drainage and human-caused fires, with $49 \%$ of the $7,200 \mathrm{~km}^{2}$ area still forested it is one of the largest areas of continuous peat-swamp forest remaining in Sumatra. The remaining area comprises acacia fibre and oil palm plantations, and community agriculture (rice, maze, sago, coconut and rubber). Land conversion in this region was rapid and extensive from the mid 1990s to 2010, with Riau province having one of the highest rates of deforestation in the country during this time (Miettinen et al., 2016). After 2013, land-use change stabilized across the central peatswamp forests through the establishment of Ecosystem Restoration Concessions, with illegal logging halted and degraded forest replanted with local native species. The peat-swamp forests of the Concessions are also being rewetted through the damming of old drainage canals. Wilting et al. (2010) noted that only $10-20 \%$ of the predicted range of the flat-headed cat is protected. Our 11 records of the species on the Kampar Peninsula provide evidence that this species can persist in privately managed landscapes such as Ecosystem Restoration Concessions where biodiversity conservation and forest protection are taking place.

Given the paucity of data, research and conservation for many of the small felids, our records of one of the rarest are of particular importance. Further research is required to elucidate the best methods for detecting the flat-headed cat (e.g. on camera type, height above ground, and camera placement) and to investigate the species' ecology and habitat requirements. This work is planned as a part of the Restorasi Ekosistem Riau programme on monitoring and conservation planning for priority species.

Acknowledgements We thank Dian Andi Syahputra and Dibyo Kusiyono of Riau Ekosistem Restorasi for deploying and collecting remote camera traps. Yuni Yanto Hadi provided GIS support. APRIL Group provides funding for the Riau Ekosistem Restorasi programme, including the surveys described here.

Author contributions Study design, fieldwork: MI; data analysis: $\mathrm{CP}$; writing: $\mathrm{CP}$.

\section{Conflicts of interest None.}

Ethical standards This research abided by the Oryx guidelines on ethical standards. 


\section{References}

Bezuijen, M.R. (2000) The occurrence of the flat-headed cat Prionailurus planiceps in south-east Sumatra. Oryx, $34,222-226$.

Cheyne, S.M. \& Macdonald, D.W. (2011) Wild felid diversity and activity patterns in Sabangau peat-swamp forest, Indonesian Borneo. Oryx, 45, 119-124.

Dommain, R., Counenberg, J. \& Joosten, H. (2011) Development and carbon sequestration of tropical peat domes in South-east Asia: links to post-glacial sea-level changes and Holocene climate variability. Quaternary Science Reviews, 30, 999.

Hearn, A.J., Cushman, S.A., Ross, J., Goossens, B., Hunter, L.T.B. \& MACDONALD, D.W. (2018) Spatio-temporal ecology of sympatric felids on Borneo. Evidence for resource partitioning? PLOS ONE, 13 , e0200828.

Jeffers, K.A., Adul \& Cheyne, S.M. (2019) Small cat surveys: 10 years of data from central Kalimantan, Indonesian Borneo. Journal of Threatened Taxa, 11, 13478-13491.

Meijaard, E., Sheil, D. \& Daryono (2005) Flat-headed cat record in east Kalimantan. Cat News, 43, 24.

Miettinen, J., Shi, C. \& Liew, S.C. (2016) Land cover distribution in the peatlands of Peninsular Malaysia, Sumatra and Borneo in 2015 with changes since 1990. Global Ecology and Conservation, $6,67-78$.
MuUL, I. \& LiM, B.L. (1970) Ecological and morphological observations of Felis planiceps. Journal of Mammalogy, 51, 806-808.

Nowell, K. \& Jackson, P. (1996) Wild Cats. Status Survey and Conservation Action Plan. IUCN/SSC Cat Specialist Group, Gland, Switzerland and Cambridge, UK.

Wadey, J., Rami, M., Moore, J., Fletcher, C. \& Compos-Arceiz, A. (2016) Flat-headed cats, Prionailurus planiceps - a literature review of their detection-rate camera-trap studies and failure to re-detect them in Pasoh Forest Reserve, Malaysia. Journal of Indonesian Natural History, 4, 22-34.

Wilting, A., Brodie, J., Cheyne, S., Hearn, A., Lynam, A., Mathai, J. et al. (2015) Prionailurus planiceps. In The IUCN Red List of Threatened Species 2015. dx.doi.org/10.2305/IUCN.UK.2015-2. RLTS.T18148A50662095.en [accessed 4 February 2021].

Wilting, A., Cheyne, S.A., Mohamed, A., Hearn, A.J., Ross, J., Hiromitsu, S. et al. (2016) Predicted distribution of the flat-headed cat Prionailurus planiceps (Mammaila: Carnivora: Felidae) on Borneo. Raffles Bulletin of Zoology, 33, 173-179.

Wilting, A., Cord, A., Hear, A.J., Hesse, D., Mohamed, A., Traeholdt, C. et al. (2010) Modelling the species distribution of flat-headed cats (Prionailurus planiceps), an Endangered South-east Asian small felid. PLOS ONE, 5, e9612.

Zanin, M., Francisco, P. \& Brito, D. (2014) What we (don't) know about the effects of habitat loss and fragmentation on felids. Oryx, 49, 96-106. 